\title{
REVITALISASI PENDIDIKAN KARAKTER MELALUI KEGIATAN TRAINING OF TRAINER (ToT)
}

\author{
Endhang Suhilmiati \\ Endangsuhilmiati11@gmail.com
}

\begin{abstract}
Abstrak
Revitalisasi Pendidikan karakter sebagai upaya pendidikan secara holistis yang menghubungkan dimensi moral dengan ranah sosial dalam kehidupan peserta didik sebagai pondasi bagi terbentuknya generasi yang berkualitas, mampu hidup mandiri dan memiliki prinsip suatu kebenaran yang dapat dipertanggungjawabkan. Atau dapat dikatakan bahwa pendidikan karakter memiliki esensi dan makna yang sama dengan pendidikan moral dan pendidikan akhlak yang bertujuan untuk membentuk pribadi anak, supaya menjadi manusia yang baik, warga masyarakat, dan warga negara yang baik dengan kriteria secara umum adalah nilai-nilai sosial tertentu, yang banyak dipengaruhi oleh budaya masyarakat dan bangsanya dalam hal ini kegiatan Training of Trainer (ToT) yang akan berdampingan beriringan dengan konsep pendidikan karakter karna pendidikan Training of Trainer adalah pelatihan yang diperuntukkan bagi siswa yang diharapkan setelah selesai pelatihan mampu menjadi pelatih dan mampu mengajarkan materi pelatihan tersebut kepada orang lain.
\end{abstract}

Kata kunci : Revitalisasi,Pendidikan Karakter,Training of Trainer

\section{PENDAHULUAN}

Pendidikan merupakan subsistem budaya yang memiliki peran strategis dalam menumbuh kembangkan potensi dan bakat manusia, pendidikan dipandang sebagai katalisator utama dalam pengembangan sumber daya manusia, dengan anggapan bahwa semakin terdidik seseorang, semakin tinggi pula tingkat kesadarannya terhadap segala hal.

Pendidikan pada hakikatnya memiliki dua tujuan, yaitu membantu manusia untuk menjadi cerdas dan pintar (smart), dan membantu mereka menjadi manusia yang baik (good). Menjadikan manusia cerdas dan pintar, boleh jadi mudah melakukannya, tetapi menjadikan manusia agar menjadi orang yang baik dan bijak, tampaknya jauh lebih sulit atau bahkan sangat sulit. Dengan demikian, sangat wajar apabila dikatakan bahwa problem moral merupakan persoalan akut atau penyakit kronis yang mengiringi kehidupan manusia kapan dan di mana pun. Kenyataan tentang akutnya problem moral inilah yang kemudian menempatkan pentingnya penyelengaraan pendidikan karakter.

Sebagai aspek kepribadian, karakter merupakan cerminan dari kepribadian secara utuh dari seseorang, mentalitas, sikap dan perilaku. Pendidikan karakter semacam ini lebih tepat sebagai pendidikan budi pekerti. Pembelajaran tentang tata-krama, sopan santun, dan adat-istiadat, menjadikan pendidikan karakter semacam ini lebih menekankan kepada perilaku-perilaku aktual tentang bagaimana seseorang dapat disebut berkepribadian baik atau tidak baik berdasarkan norma-norma yang bersifat kontekstual dan kultural.

Menurunnya kualitas moral dalam kehidupan manusia Indonesia dewasa ini, terutama dikalangan siswa, menuntut diselenggarakannya pendidikan karakter. Sekolah untuk memainkan peran dan tanggung 
jawabnya menanamkan dan mengembangkan nilai-nilai yang baik dan membantu para siswa membentuk dan membangun karakter mereka dengan nilai-nilai yang baik. Pendidikan karakter diarahkan untuk memberikan tekanan pada nilai-nilai tertentu, seperti rasa hormat, tanggungjawab, jujur, peduli, dan adil, serta membantu siswa untuk memahami, memperhatikan, dan melakukan nilai-nilai tersebut dalam kehidupan mereka sendiri (Haryanto, 2012).

Ki Hadjar Dewantara menyatakan bahwa pendidikan adalah daya upaya untuk memajukan budi pekerti, pikiran, dan jasmani anak agar selaras dengan alam dan masyarakatnya. Sedangkan secara terminologi, pengertian pendidikan banyak sekali dimunculkan oleh para pemerhati/tokoh pendidikan, di antaranya: Pertama, menurut Marimba pendidikan adalah bimbingan atau pimpinan secara sadar oleh pendidik terhadap perkembangan jasmani dan rohani anak didik menuju terbentuknya kepribadian yang utama.

Dalam Undang-Undang Nomor 20 Tahun 2003 tentang Sistem Pendidikan Nasional dalam Pasal 1 ayat (1) disebutkan bahwa pendidikan adalah usaha sadar dan terencana untuk mewujudkan suasana belajar dan proses pembelajaran agar anak didik secara aktif mengembangkan potensi dirinya untuk memiliki kekuatan spiritual keagamaan, pengendalian diri, kepribadian, kecerdasan, akhlak mulia, serta keterampilan yang diperlukan dirinya, masyarakat, bangsa dan negara. Intinya pendidikan selain sebagai proses humanisasi, pendidikan juga merupakan usaha untuk membantu manusia mengembangkan seluruh potensi yang dimilikinya (olahrasa, raga dan rasio) untuk mencapai kesuksesan dalam kehidupan dunia dan akhirat.

Istilah karakter berasal dari bahasa Yunani, charassein, yang berarti to engrave atau mengukir. Membentuk karakter diibaratkan seperti mengukir di atas batu permata atau permukaan besi yang keras. Dari sanalah kemudian berkembang pengertian karakter yang diartikan sebagai tanda khusus atau pola perilaku (an individual's pattern of behavior ... his moral contitution).
Karakter diartikan sebagai sifat manusia pada umumnya dimana manusia mempunyai banyak sifat yang tergantung dari faktor kehidupannya sendiri. Karakter adalah sifat kejiwaan, akhlak atau budi pekerti yang menjadi ciri khas seseorang atau sekelompok orang.

Pengertian Pendidikan Karakter adalah "sebuah usaha untuk mendidik anak-anak agar dapat mengambil keputusan dengan bijak dan mempraktekkannya dalam kehidupan seharihari, sehingga mereka dapat memberikan kontribusi yang positif kepada lingkungannya" ( Ratna Megawati dalam Kusuma, Chepi Triatna dan Johar Permana, 2011:5).

Dalam hal ini revitalisasi yang ditekankan adalah pengembangan karakter siswa melalui kegiatan Training Of Trainer. Mendidik agar siswa berani berbicara dan berkomunikasi di depan orang banyak. Karena menjadi seorang trainer di butuhkan kecakapan penuh dalam penguasaan materi dan public speakingnya. Melatih kemandirian, disiplin, dan rasa tanggung jawab dalam mengelola suatu kegiatan.

Berangkat dari uraian diatas, maka penulis merasa perlu melakukan studi kajian terhadap "Revitalisasi Pendidikan Karakter Melalui Kegiatan Training Of Trainer (ToT)

\section{PEMBAHASAN}

\section{A. Revitalisasi Pendidikan Karakter}

\section{Pengertian Revitalisasi Pendidikan Karakter}

Dalam kamus besar Bahasa Indonesia, Revitalisasi berarti proses, cara, dan perbuatan menghidupkan kembali suatu hal yang sebelumnya kurang terberdaya. Sebenarnya revitalisasi berarti menjadikan sesuatu atau perbuatan menjadi vital. Sedangkan kata vital mempunyai arti sangat penting atau perlu sekali (untuk kehidupan dan sebagainya). Pengertian melalui bahasa lainnya revitalisasi bisa berarti proses, cara, dan atau perbuatan untuk menghidupkan atau menggiatkan kembali berbagai program kegiatan apapun. Atau lebih jelas revitalisasi itu adalah membangkitkan kembali vitalitas. Jadi, pengertian revitalisasi 
ini secara umum adalah usaha-usaha untuk menjadikan sesuatu itu menjadi penting dan perlu sekali.

Pengertian Pendidikan. "pendidikan adalah kegiatan membimbing anak manusia menuju pada kedewasaan dan mandiri" (M.J. Langeveld dalam Jumali (2004: 20). Sedangkan rumusan pendidikan sebagaimana dalam UU No.20 Tahun 2003 adalah: Usaha sadar dan terencana untuk menciptakan suasana belajar agar peserta didik secara aktif mengembangkan potensi dirinya untuk memiliki kekuatan spiritual keagamaan, pengendalian diri, keppribadian, kecerdasan, sikap sosial dan ketrampilan yang diperlukan dirinya, masyarakat, bangsa dan negara (pasal 1).

Kata karakter (Inggris: character) secara etimologis berasal dari bahasa Yunani, yaitu charassein yang berarti "to engrave" (Ryan and Bohlin, 1999). Kata "to engrave" bisa diterjemahkan mengukir, melukis, memahatkan, atau menggoreskan (Echols dan Shadily, 1995). Dalam Kamus Bahasa Indonesia kata "karakter"diartikan dengan tabiat, sifat-sifat kejiwaan, akhlak atau budi pekerti yang membedakanseseorang dengan yang lain, dan watak. Karakter juga bisa berarti huruf, angka, ruang, simbol khusus yang dapat dimunculkan pada layar dengan papan ketik (Pusat Bahasa Depdiknas, 2008). Orang berkarakter berarti orang yang berkepribadian, berperilaku, bersifat, bertabiat, atau berwatak. Dengan makna seperti itu berarti karakter identik dengan akhlak.

Secara terminologis karakter adalah "A reliable inner disposition to respond to situations in a morally good way." Selanjutnya Lickona menambahkan, "Character so conceived has three interrelated parts: moral knowing, moral feeling, and moral behavior" (Lickona, 1991). Menurut Lickona, karakter mulia (good character) meliputi pengetahuan tentang kebaikan (moral knowing), lalu menimbulkan komitmen (niat) terhadap kebaikan (moral feeling), dan akhirnya benarbenar melakukan kebaikan (moral behavior) (dalam Marzuki, 2009).
Williams \& Schnaps (1999) sebagaimana dikutip Haryanto (2012) mendefinisikan pendidikan karakter sebagai "any deliberate approach by which school personnel, often in conjunction with parents and community members, helpchildrenandyouthbecomecaring, principled and responsible". Maknanya, pendidikan karakter merupakan berbagai usaha yang dilakukan oleh para personil sekolah, bahkan yang dilakukan bersama-sama dengan orang tua dan anggota masyarakat, untuk membantu anak-anak dan remaja agar menjadi atau memiliki sifat peduli, berpendirian, dan bertanggung jawab.

Menurut Hidayatullah (2010: 16), karakter adalah kualitas atau kekuatan mental atau moral, akhlak atau budi pekerti individu yang merupakan kepribadian khusus yang menjadi dorongan dan penggerakan, serta yang membedakan dengan ndividu lain.

Pengertian Pendidikan Karakter adalah "sebuah usaha untuk mendidik anak-anak agar dapat mengambil keputusan dengan bijak dan mempraktekkannya dalam kehidupan seharihari, sehingga mereka dapat memberikan kontribusi yang positif kepada lingkungannya" ( Ratna Megawati dalam Kusuma, Chepi Triatna dan Johar Permana, 2011: 5).

Pendidikan karakter sebenarnya merupakan bagian esensial yang menjadi tugas sekolah. Selain pencapaian dari sisi akademis yang memuaskan, seharusnya sekolah tetap bertanggung jawab dalam pembentukan karakter siswa. Namun dalam kenyataannya 2 hal ini belum bisa berjalan secara selaras, karena pencapaian akademis mengalahkan idealitas peran sekolah dalam pembentukan karakter. Terkait dengan pendidikan karakter ini, berkembang berbagai definisi dari banyak ahli.

Raharjo (2010) mengasumsikan pendidikan karakter secara lebih luas lagi yakni suatu proses pendidikan secara holistis yang menghubungkan dimensi moral dengan ranah sosial dalam kehidupan peserta didik sebagai pondasi bagi terbentuknya generasi yang berkualitas, mampu hidup mandiri dan memiliki prinsip suatu kebenaran yang dapat dipertanggungjawabkan. Atau dapat dikatakan 
bahwa pendidikan karakter memiliki esensi dan makna yang sama dengan pendidikan moral dan pendidikan akhlak yang bertujuan untuk membentuk pribadi anak, supaya menjadi manusia yang baik, warga masyarakat, dan warga negara yang baik dengan kriteria secara umum adalah nilai-nilai sosial tertentu, yang banyak dipengaruhi oleh budaya masyarakat dan bangsanya.

Dari pemaparan di atas dapat ditarik kesimpulan bahwa pendidikan karakter adalah Proses Pendidikan yang membentuk karakter pribadi manusia menjadi lebih baik.

\section{Pentingnya Pendidikan Karakter}

Thomas Lickona (dalam Haryanto, 2012) menyadarkan dunia akan pentingnya pendidikan karakter. Secara terinci, Lickona mengemukakan tujuh alasan mengapa pendidikan karakter itu harus dilakukan:

a. Merupkan cara terbaik untuk menjamin anak-anak (siswa) memiliki kepribadian yang baik dalam kehidupannya.

b. Merupakan cara untuk meningkatkan prestasi akademik.

c. Sebagian siswa tidak dapat membentuk karakter yang kuat bagi dirinya di tempat lain

d. Mempersiapkan siswa untuk menghormati pihak atau orang lain dan dapat hidup dalam masyarakat yang beragama.

e. Berangkat dari akar masalah yang berkaitan dengan problem moral-sosial, seperti ketidaksopanan, ketidakjujuran, kekerasan, pelanggaran kegiatan seksual, dan etos kerja (belajar) yang rendah.

f. Merupakan persiapan terbaik untuk menyongsong perilaku di tempat kerja;.

g. Mengajarkan nilai-nilai budaya merupakan bagian dari kerja peradaban

\section{Langkah Revitalisasi Pendidkan Karakter}

Langkah strategis dari revitalisasi pendidikan karakter dapat dimulai dari membenahi pendidikan yaitu dengan cara mengintegrasikan nilai-nilai karakter dalam kurikulum pendidikan. Dalam konteks demikian maka, nilai-nilai karakter yang akan ditanamkan kepada bangsa Indonesia adalah nilai-nilai karakter yang telah dimiliki oleh masyarakat melalui proses internalisasi.

Adapun nilai-nilai karakter yang perlu dimiliki oleh anak yang dapat diintegrasikan ke dalam kurikulum adalah sebagai berikut; (1) Nilai-nilai spiritual yaitu nilai keberagamaan yang berorientasi kepada etika dan akhlak serta penyeimbang antara ke saleha individu dan sosial seperti taat beragama, maju berbudaya ; (2) Nilai-nilai solidaritas kebangsaan yang harmosia dan dinamis yang perlu ditanamkan seperti kebiasaan hidup berdampingan secara damai, saling memahami, menghormati, tolong menolong untuk kemajuan bangsa dan negara; (3) Nilai-nilai kedisiplinan yaitu membiasakan agar selalu tepat pada waktu, dan menyadari norma-norma hukum yang berlaku; (4) Nilai-nilai kemandirian, seperti melatih untuk melakukan sesuatu dengan usaha sendiri tidak selalu bergantung kepada orang lain; (5) Niali-nilai kemajuan dan keunggulan seperti membangun karakter yang selalu berorientasi kepada prestasi dan semangat kerja (Nawawi, 2011:5).

Kemudian nilai-nilai karakter lain yang dapat diintegrasikan dalam kurikulum yaitu nilai-nilai yang dimiliki oleh manusia Indonesia misalnya; 1) Nilai religius; yang dicirikan oleh sikap hidup dan kepribadian seperti taat beribadah, jujur, terpercaya, dermawan, saling tolong menolong dan toleran, 2) Moderat yang dicirikan dari sikap hidup yang tidak radikal, kepribadian tengahan antara individu dan sosial, berorientasi materi dan rohani, hidup bersama dalam kemajemukan, 3) Cerdas yang dicirikan oleh sikap hidup rasional, cinta ilmu, terbuka, dan berpikiran maju, 4) Mandiri yang dicirikan oleh sikap hidup mereka, disiplin, hemat, menghargai waktu, ulet, wirausaha, kerja keras, cinta bangsa tanpa kehilangan orientasi ( PP-Muhammadiyah, 2009).

\section{B. Pengertian Tentang Training Of Trainer (ToT) \\ Training of Trainer atau dalam bahasa}


Indonesia adalah Pelatihan untuk Pelatih. Definisi secara luasnya adalah adalah pelatihan yang diperuntukkan bagi orang yang diharapkan setelah selesai pelatihan mampu menjadi pelatih dan mampu mengajarkan materi pelatihan tersebut kepada orang lain.

Sebelum kita membahas lebih jauh mengenai Training of Trainer, kita perlu memahami definisi dari training atau pelatihan terlebih dahulu. Secara umum Training atau pelatihan dapat didefinisikan sebagai proses pemindahan pengetahuan dan keterampilan dari seseorang kepada orang lain sehingga orang lain menjadi cakap dalam pekerjaannya. Kegiatan tersebut tidak dibatasi oleh lokasi ataupun formalitasnya karena dimana pun tempatnya, apabila terjadi suatu proses pemindahan pengetahuan/keterampilan kepada orang lain maka itu bisa dikatakan sebagai training.

Secara umum ada 3 tahapan untuk melaksanakan Training of Trainer (TOT), masing-masing tahapan pelatihan tersebut mempunyai tujuan yang berbeda. Berikut adalah 3 tahapan dari training of trainer, yaitu antara lain:

\section{Pelatihan ketrampilan melatih (training delivery)}

Pelatihan ketrampilan melatih (training delivery) dilakukan juga dalam rangka untuk memberikan kemampuan penguasaan materi kepada para trainer agar para trainer bisa memberikan pelatihan terhadap suatu subyek. Oleh karena itu kita sering mendengar kata TOT diikuti dengan subyek kata yang lain, namun pada dasarnya tujuan kegiatan itu tetap sama, yaitu agar peserta pelatihan mampu melatih.

\section{Pelatihan menyusun langkah atau tahapan melatih (session design)}

Pelatihan menyusun langkah atau tahapan melatih (session design) adalah pelatihan yang ditujukan agar para trainer dapat menyusun dan merancang sebuah materi pelatihan. Dalam kegiatan merancang sebuah pelatihan maka seorang trainer harus melakukan beberapa hal, yaitu: a. Identifikasi kebutuhan training

b. Merumuskan tujuan training

c. Menyusun Silabus

d. Cara penyajian materi training

e. Membuat metode evaluasi

\section{Pelatihan ketrampilan mendisain kurikulum pelatihan (curriculum design)}

Pelatihan ketrampilan mendisain kurikulum pelatihan (curriculum design) adalah langkah selanjutnya dari tahapan Training of Trainer ini, yaitu para trainer diharuskan mampu membuat silabus training. Yang perlu diingat disini adalah silabus tidak sama dengan materi. Cara membuat silabus Training adalah sebagai berikut:

a. Tentukan ability yang ingin dicapai.

b. Indikator apa yang menandakan tercapainya ability tersebut?

c. Apa yang perlu diketahui seseorang agar bisa menguasai ability tersebut?

d. Apa yang perlu dilakukan seseorang agar bisa menguasai ability tersebut.

e. Susunlah materi tersebut secara urut dan sistematis.

\section{PENUTUP}

Keberhasilan revitalisasi pendidikan melalui kegiatan training of trainer perlu adanya dukungan dan kerjasama oleh semua pihak terutama guru sebagai pelaku dari perubahan yang memiliki peran utama sebagai pendidik karakter dan sebagai trainer yang baik.pendidikan karakter mempunyai peranan yang sangat penting bagi nasib sebuah bangsa di masa yang akan datang oleh karena itu pendidikan karakter melalui kegiatan training of trainer di harapkan menjadi salah satu pilihan dalam merevilitasi nilai nilai karakter bangsa melalui pengintrogasianya kedalam kurikulum yang bersifat holistik,sehingga keresahan dalam dunia pendidikan tidak akan terjadi lagi serta membuat bangsa Indonesia memiliki jati diri dan martabat yang tinggi di kalangan Internasional. 


\section{DAFTAR PUSTAKA}

Al Bahry, Dahlan. 1994. Kamus Ilmiah Popular. Surabaya: Arkola.

Arikunto, suharsimi. 2006. Prosedur penelitian Suatau pendekatan Praktik .Jakarta: PT. Rineka Cipta.

Bochori, Muhammad, Character Building dan Pendidikan Kita. Kompas 21

Bungis, Burhan. 2005. Metodologi penelitian kuantitatif. Jakarta: Prenada Media.

http:/heartspeaks.co.id. diakses tanggal 23 Februari 2017

Hamalik, oemar. 2007. Dasar-dasar Pengembangan Kurikulum. Bandung: Sinar Baru Algensindo.

Iskandarwassid. 2008. Strategi pembelajaran Bahasa. Bandung: PT. Remaja Rosdakarya.

Ridwan. 2008. Ketercapaian Prestasi Belajar (serial online), Ridwan.Wordpress .Com. Diakses 22 Februari 2017.
Sabur, Alex. 2003. Psikologi Umum. Bandung: CV Pustaka Setia.

Sirozi, Muhammad. 2011. Mengefektifkan Pendidkan Karakter. Blogspot.com. diakses 23 Februari 2017

Sudjana. 2005. Metode Statistika. Bandung: PT. Tarsito Bandung.

Sugiyono. 2007. Metode Penelitian Kuantitatif dan Kualitatif. Bandung : Alfabeta.

Nofrizal, Nawawi, 2011. "Pendidikan Karakter dengan Pendekatan Nilai-nilai Keagamaan" Makalah disajikan pada semiloka pendidikan karakter bangsa: Palembang.

PP Muhammadiyah-Revitalisasi Visi dan Karakter Bangsa: 2009.

Sirozi, Muhammad, 2011."Mengefektifkan Pendidikan Karakter" Makalah disajikan pada semiloka pendidikan karakter bangsa di Palembang. 